\title{
THE DECOLONIAL OPTION: IMPLICATIONS FOR THE CURRICULUM OF FOREIGN LANGUAGE TEACHER EDUCATION PROGRAMS
}

\section{LA OPCIÓN DECOLONIAL: IMPLICACIONES PARA EL CURRÍCULO DE PROGRAMAS DE FORMACIÓN DE DOCENTES EN LENGUAS EXTRANJERAS}

\author{
Alexánder Ramírez Espinosa ${ }^{2}$ \\ Universidad del Valle, Cali, Colombia
}

\section{ABSTRACT}

This reflection article derives from the discussions and argumentative sessions that took place at
Theories. With this paper, the author intends a twofold purpose: on the one hand, to present his perceptions about the literature analyzed and discussed along the seminar, and on the other, to shed light on how such literature can have a positive impact on the curricula of Foreign Language Teacher Education Programs. The ideas that the author puts forward are the product of discussions with colleagues and teachers; in that sense, the arguments presented here are open to further scrutiny and academic dialogue with other scholars. It is hoped that this article contributes to the current discussions on the construction of curricula, the teaching of foreign languages from an emancipatory perspective, and the search for social justice in education.

$1 \quad$ This paper stems from the discussions and argumentative sessions within the Decolonial Theories seminar, offered in the Interinstitutional Doctorate program in Education at Universidad del Valle, in Cali-Colombia.

$2 \quad$ Universidad del Valle, Cali - Colombia alexander.ramirez.e@correounivalle.edu.co https://orcid. org/ 0000-0002-7122-9537

\section{KEY WORDS}

Decolonial Theories, Decolonial Option, Foreign Language Teaching, Social Justice, Curriculum.

\section{RESUMEN}

Este artículo de reflexión se deriva de las discusiones y sesiones argumentativas que se dieron en el marco de un seminario doctoral sobre Teorías Decoloniales. Con este artículo, el autor se propone un doble objetivo: por un lado, presentar sus reflexiones en torno a la literatura revisada y discutida a lo largo del seminario, y por otro, arrojar luz sobre cómo dicha literatura puede tener un impacto positivo en los currículos de programas de formación de dicentes en lengua extranjera. Los argumentos que el autor presenta aquí son producto de las discusiones con colegas y docentes; en ese sentido, las ideas aquí presentadas están abiertas al escrutinio y al diálogo por parte de otros académicos. Se espera que este artículo contribuya a las discusiones actuales sobre la construcción de currículos y la enseñanza de lenguas extranjeras desde una mirada emancipadora, y la búsqueda de justicia social en la educación. 


\section{PALABRAS CLAVE}

Teorías Decoloniales, Opción Decolonial, Enseñanza de Lenguas Extranjeras, Justicia Social, Currículo.

\section{INTRODUCTION}

The current globalized world poses many complexities, as well as advantages, for the ways humans live nowadays: modern transportation, communication technologies, the Internet and social networks have made a huge impact in the way people across countries interact, negotiate and collaborate. But the same factors that bring us together, also make us prompt to conflict (Jackson, 2014), pushing the world towards a state of global upheaval.

Similarly, globalization has uncovered ancient and longstanding social inequalities stemming from the differences in race, age, gender, sexual orientation, or regional background, just to name a few. Such inequalities might not be new, but $\begin{array}{llll}1 & 0 & 3\end{array}$ they are more evident than ever, which makes people more aware of the injustices committed against others and against themselves. Not surprisingly, in a world where injustice based on difference is sadly and increasingly the norm, the fields of Social Sciences and Humanities have placed a great deal of research attention in concepts such as critical theory, decoloniality, and social justice.

Languages are not alien to this new reality. On the contrary, today more than ever we hear of bilingualism, multilingualism, and interculturality, as phenomena that affect everyone. What is paradoxical, however, is that the languages that unite human beings in communication, mutual understanding, negotiation of meanings, and conflict resolution, are also a differentiating factor that separates the world into a sort of linguistic castes that do not escape to the logic of colonial hegemony. It is against this background that this paper is written with a twofold purpose: first, it presents my reflections on some of the literature revised around the topic of decolonial theories, and second it sheds light on how these works may constitute the foundations for a solid paradigm shift (Reagan \& Osborn, 2019), especially in a Foreign Language Teacher Education (FLTE) Program.

\section{WHAT DOES DECOLONIALITY ENTAIL?}

Understanding decoloniality depends on understanding first what coloniality means. The prominent work of Quijano (1992) defines coloniality as a political, social and cultural direct domination of Europeans over Latin America and African countries. On a similar token, Tlostanova and Mignolo (2009) define coloniality as the dependence from an imperial organization of society, that rules our thoughts, as well as our forms of thinking and being; this "subtle" imperialism is "the hidden side of modernity" (p. 132) as there can be "no modernity without coloniality" (Tlostanova \& Mignolo, 2009, p.132). As a result, our societies struggle in a constant quarrel of uneven power relationships where dominant groups (be they cultural, ethnic, political, religious, or even academic groups/ elites) exert oppression over some dominated groups. In that sense, our vision of the world, as well as the institutions and categories we use to organize our societies and make meaning out of our surrounding reality, are the product of colonization processes as well as the product of modernity.

Decoloniality, therefore, is the radical response of the oppressed, whereby societies are encouraged to "question the ways in which power works through the discursive practices and performances of schooling" (Popkewitz, 1999 , p. 1). Decoloniality is the banner of postmodernism, and the process of identifying and reverting longstanding inequalities. It is a wake-up call for all human beings to be aware of the hidden agendas and ruling powers that control our societies; but apart from being merely aware, decoloniality implies action: it 
entails "epistemically and effectively delinking from the imperial/colonial organization of society" (Tlostanova \& Mignolo, 2009, p.132). In other words, once we become aware of the colonial system(s) that surround us and that we have somehow helped to maintain, our coherent choice is no other than rupturing such a yoke (Macedo, 2019), and acting against it.

The dyad Awareness-Action is at the heart of what different authors have called the decolonial option (Kumaravadivelu, 2016; Monzó \& McLaren, 2014; Tlostanova \& Mignolo, 2009). Put differently, the core of the decolonial option is the transformation of hegemonic powers into actions for social justice. This, however, is far from being a smooth process, especially because when adopting the decolonial option, we have to acknowledge that we have also been perpetrators of unequal power relationships, we have also fostered inequalities in different contexts, and we have been pawns inflicting oppression upon others, in representation of the colonial systems that permeate all contexts of society. In educational contexts, for instance, teachers have both suffered the burden of neoliberal policies of governments and exerted a colonial control over their students (usually by means of evaluation). In other words, we all have been both victims and tormentors.

In what remains of this paper, I focus on the field of Language Teacher Education, as one of the many educational contexts in which a decolonial option is needed. I start by sketching out the need for a paradigm shift (Reagan \& Osborn, 2019), and I go on to presenting the specific areas where the decolonial option can transform the curricula of Foreign Language Teacher Education Programs (hereinafter, FLTE) in Colombia.

\section{THE DECOLONIAL OPTION IN FL TEACHER EDUCATION: WHY IS IT NEEDED?}

The decolonial option is an urgent endeavor in education, because education is a field of ideological reproduction that can carry on traditionally perverse paradigms, or implement new paradigms ofawareness, empathy, and social justice. According to Solano (2015) decolonizing the field of education implies to work in search for the emancipation from traditional paradigms "that bind education, school, pedagogy and culture to a civilizational model in crisis"3 (p.123). Such paradigms, Solano (2015) explains, are rooted in the way education and its institutions reproduce practices, beliefs, knowledge and forms of social organization that foster sociocultural subalternization; our worldview and comprehension of reality is decanted through those paradigms. In that sense, decolonizing education implies "breaking the traditional ways in which things are conceived and done simply because they have always been that way" (Solano, 2015, p.124).In other words, the decolonial option must contribute to the "creation of a new human being, one who is capable of questioning the society where he/she is in order to propose new knowledge, values, interactions and logics" (García-González, 2020).

While the decolonial option is indispensable in all spheres of society in general, and education in particular, in the field of FLTE such an option is doubly necessary. The reason is that language is a reproductive mechanism of colonial and hegemonic bonds. Language is one of the first means through which we approach the task of understanding the world in which we live; it is through language that we acquire the notions of authority, of power, of who owns it, of who inflicts it, of who suffers it. Language passes down to the generations the inheritance of concepts of social hierarchies, imposes on us the status quo of the limits that divide the world, and marks out the boundaries that determine who we are and who others are, who belongs and who does not.

$3 \quad$ All translations into English of previously untranslated works are mine. 
More particularly, foreign languages have always been a tool for colonization, either physical and violent or in symbolic and subtle ways. Foreign languages are the vehicle whereby certain cultures are granted more prestige, while others are sent to be last from the totem pole. Foreign languages hold the power of reproducing and spreading out stereotypes, but they are also the means for the voices that oppose or counteract such stereotypes. Foreign languages can be the first step to colonize the minds and cultural practices of other people, but they can also be the instrument for reverting coloniality, frank discussion in search of political debates and democratic participation. Therefore, in the spirit of transformation that lies at the core of the decolonial option, language in general, and foreign languages, can also be the tools for the transformation and emancipation of ideas, communication and human relationships.

The arguments are not far to seek as to why foreign languages can be either the weapon of coloniality, or the bastion of revolt and change. With this in mind, the field of FLTE constitutes the seedbed over which change for the future generations can be promoted; pre-service FL teachers have the potential of making a huge impact in terms of how the future generations will use languages, both mother tongue and foreign ones, to participate in international scenarios and make their voices heard. Accordingly, FLTE programs must strive for the decolonial option in search for the emancipation of preservice teachers: an emancipation of the self, of epistemologies, of pedagogies, of languages, and finally, an emancipation that will allow for the heterarchical thought in our society (Kontopolous, 1993, as cited in Castro-Gómez and Grosfoguel, 2007, p.18). As teachers to be, they hold the power and the responsibility of educating the generations to come, and finally establishing a paradigm shift in education.

\section{DECOLONIZING THE CURRICULUM OF FLTE PROGRAMS}

This section is devoted to analyzing and reflecting over some core elements of curriculum that can be transformed by adopting the decolonial option. Reagan and Osborn (2019) building on previous works by Altbach (1971) state that the curriculum of schools and colleges reproduce and sustain colonial practices of the dominant rulers; the curriculum, these authors assert, has been neglected in favor of international models, which end up importing an ideological burden that sustains the positionalities of the powerful over the oppressed. With this in mind, I agree with Reagan and Osborn (2019) that "it is time for some radical rethinking of the nature, purpose, and goals of foreign language education in our society" (p. 90), or as they would call it, a true paradigm shift. Although my arguments, criticism, ideas, and proposals are bound to the particular context where I work, which is the field of foreign language Teacher Education programs, I truly hope these reflections might also pave the way for other fields. These are the curricular elements that I see as opportunities for a decolonial option, aiming at a paradigm shift:

\section{- MOVING TOWARDS THE DE- HIERARCHIZATION OF KNOWLEDGE AND OF PEDAGOGICAL RELATIONSHIPS}

One of the most salient features of a colonized educational model is hierarchy: teachers establish vertical relationships of superiority and power over students; likewise, depending on their area of expertise, some teachers maintain this verticality with other colleagues, in a logic that knowledge in certain fields is more important than in others. In Albornoz's (2012) words:

This logic of "instructing" the student, differentiating knowledge by positions of importance from, is a reflection of our history as a colonized people, where it was others who 
'civilized' us in this territory, it was others who brought customs, plans, architecture, religion and they establish them, being the inhabitants of this territory the recipients, the "educated", the colonized ones by practices that were legitimized, by means of an authoritarian praxis most of the time. (p. 331).

Thus, if we agree with the fact that education is a political act, then the decolonial option is the way to promote a democratic education that breaks, once and for all, with the banking practice of knowledge whereby teachers deposit knowledge in the recipient learners, in a transactional fashion (Freire, 1997). Instead, we need to strive for pedagogical relationships where knowledge takes places by means of collaborative acts, where all participants -teachers and studentscan make relevant contributions to the process. This implies a change in the traditional roles of teachers and students, as their relationship will no longer be based on power enforcement.

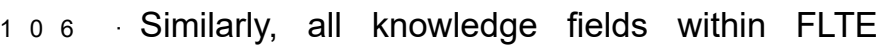
curricula (linguistics, pedagogy, research, mother tongue, foreign languages, among others) must be understood as complementary endeavors towards the educational upbringing of critical human beings, and not as independent parcels in a hierarchy of importance.

\section{AN EXPLICIT DEFINITION AND ACKNOWLEDGMENT OF LANGUAGES, THEIR STATUS AND THEIR ROLES IN EDUCATION}

From the very beginning of the major, FLTE programs must address explicitly the socialization, among pre-service teachers, of the institutional conception of multilingualism, as well as the institutional acknowledgement of mother tongue(s), foreign languages, and their roles within the curriculum. In other words, the curriculum must be the reflection of clear linguistic policies in the institution, through which the languages that students bring to the classroom, and the languages that they are taught in the institution, are treated with equal respect. In Colombia, for instance, the official language -Spanish- interacts with more than 60 indigenous languages, one sign language, and two creole languages, as well as with the foreign languages that have been imported into curricula (Miranda,2016; De Mejía, 2016). This multilingual context, which many Colombians are not even aware of, demands clear policies that guarantee linguistic rights to speakers of all the languages spoken in the territory; in a foreign language classroom, for example, there is nothing more colonizing than depriving students from their right to use their mother tongue, as it establishes a dangerous hierarchy of languages in the mindsets of future teachers. FLTE programs must disseminate awareness among pre-service FL teachers about our linguistic diversity and richness.

Furthermore, pre-service teachers must be early introduced to the critical analysis of the nativespeakerism fallacy, as well as to the avoidance of traces of linguistic supremacy, that beget negative ideologies both in the foreign languages and the mother tongue (e.g., the idea that certain regional accents in Colombia are better or "more elegant" than others").

\section{- TOWARDS AN INTERCULTURAL APPROACH IN LANGUAGE TEACHER EDUCATION}

The need for an intercultural approach in second language teaching has been pointed out since the late 1980s, yet culture has been marginal to the curriculum of communicative language teaching despite the relevance that culture has for language teachers (Corbett, 2003). A reason for this might be the lack of systematic models to include culture in the curriculum (Corbett, 2003). Authors such as Palaiologou and Dietz (2012) argue that "the struggle for multicultural and/or intercultural education is increasingly justified by the apparent inability of the majority society to meet the new challenges created by 
the heterogeneity of pupils" (p.7). In other words, the constantly changing world has also changed our classrooms in terms of diversity, so much so that cultural aspects are no longer an option but a compulsory requirement in curricula. On a similar token, Reagan and Osborn (2019) call for a true paradigm shift, whereby an intercultural approach enriches the languagelearning experience and contributes to the global educational goals "of better understanding one's own community as well as those of others" (Corbet, 2003, p.44). In a nutshell,

FLTE curricula need to be designed around an intercultural approach across, so that the core of language teaching may be an ample understanding and respect for cultures (Kramsch, 1993). Such an approach is an urgency, not merely because of the changes in communications technology, transportation, and changing demographics of the current globalized world (Jackson, 2014), as well as the demands of internationalized and multilingual educational systems (Griffith et al, 2016), but also because an intercultural orientation is a humanistic way of viewing the world (Liddicoat, 2021).

\section{- $\quad$ DECOLONIZATION OF FL TEXTBOOKS AND MATERIALS}

Textbooks and language teaching materials hold the power to encourage perspectives and to spread ideologies -both linguistic and cultural ones- about others. Such ideologies may be biased, colonized and stereotypical, which is the reason why the decolonization of textbooks and materials is a must. In this regard, Núñez-Pardo (2020) asserts that FL textbooks "ways of being, knowing, and exerting power that hide, distort or misrepresent the multiplicity of sociocultural realities in local contexts" (p.122). Even though FLTE program might use textbooks or not, the pre-service teachers that these programs educate will have to use them at some point in their future jobs. Therefore, they must be taught how to analyze these materials in search for colonizing elements, and what is more, preservice teachers need to learn the way in which those textbooks materials can actually be used with decolonizing purposes. As Tomlinson (2016) puts it, textbooks and materials are not good or bad in themselves, it is the use that teachers make out of them which holds the potential of transformative or decolonial practices in our classrooms.

The decolonial option, then, must serve the purpose of encouraging pre-service and inservice language teachers to design materials and textbooks "....informed by locally emerging content and methods that are sensitive to cultural diversity (Núñez-Pardo, 2020, p.123). The portrayal of diversity in textbooks and materials has to transcend the conventional focus on ethnicity, and has to allow for the display of an ample plethora of otherness: age, social status, gender constructions, physical capacities, religion, etc.; in other words, decolonizing the FL materials and textbooks implies an approach that surpasses "diversity out there" and focuses on "diversity withing the context's borders" (McKay, 2021).

We need to show pre-service teachers how to design classroom materials and activities that explore dissident points of view, that bring up transgressive themes, we need to explore authors from diverse backgrounds, from minority and minoritized communities, with particular worldviews that challenge conventional normative taboos. As pointed out by Ramírez et al (2019):

Language belongs to the one who uses it and, therefore, it is valid to put the foreign languages that we teach in the mouth of the non-native, the immigrant speaker, the oppressed, the marginal and, in general, in the mouth of anyone who has a story to confront us (p. 11). 


\section{- DECOLONIZATION OF EVALUATION AND TESTING PRACTICES}

Evaluation in education portrays traces of colonization when it serves the purpose of domination and punitive actions. To this respect, Foucault (1995) asserts that "the superimposition of the power relations and knowledge relations assumes in the examination all its visible brilliance" (p.185). Although much has been said about how evaluation and testing has been used as a tool for repressive power, and how high-stake decisions based on testing results can have detrimental effect on students (Shohamy, 2001), however I still consider necessary to insist on how evaluation, if not done correctly, con booster a chain of hegemonic power: the system inflicts repression on state teachers and teacher educators; these teachers use evaluation as a repressive practice on pre-service teachers, and these latter end up reproducing the same power abuse on their students. In Shohamy's (1991) words, the "use of tests occurs at all levels -teachers with students, principals with teachers, regional officials with principles and national authorities with regional officials" (Shohamy, 1991, p. 35). While evaluation and general and testing in particular are bound to the field of Foreign Language Teaching, FLTE programs need to offer a broad critical vision of what evaluation and testing entails, as well as a frank analysis of the colonizing practices of tests, standardized examinations and the gatekeeping practices of assessing language levels for university or college entry.

Our curricula need to prepare future teachers to analyze and identify all traces of colonization in evaluation practices. Repressive evaluation exerts manipulation, since it allows a few in authority (government, institutions, teachers, etc.) to impose behaviors on others and determine what those others should know, and whether they know it or not. Thus, it is necessary the curricula of FLTE programs need to foster critical evaluation practices, not only because of the power that underlies evaluation, but also because of the power underlies languages.

\section{- $\quad$ RESEARCH AND EPISTEMOLOGIES}

The way to produce knowledge, as well as the fields in which knowledge is more appreciated also constitute a trace of coloniality. The decolonial turn should lead us to value other forms of knowledge, to avoid hierarchizing certain topics or fields over others, to guarantee the legitimacy that each form of research and knowledge production deserves. Epistemological decolonization is a must because it is the only way to "open a path to a new inter-cultural communication, to an exchange of experiences and meanings, as the basis of another rationality that can claim, with legitimacy, some universality" (Quijano, 1992, p. 447). As an anecdote, for instance, in one of the FLTE programs where I worked, when pre-service teachers are about to graduate and have to comply with their senior thesis, some of them get interested in working with the Colombian Sign Language (CSL), or with an indigenous language, or with the description of the Spanish variety of a minority group (the LGBTI+ Community, for example). As a consequence, there is, among some teacher educators, a constant debate over whether the pre-service teachers should be allowed to conduct such studies as part of their graduation requirements. Consequently, there are usually those who question whether preservice teachers should be allowed to work in such fields even if they will graduate as foreign language teachers. The rationale behind their arguments hint traces of a very colonized mind, usually favoring the idea that a senior thesis in foreign language teaching is more valuable than a research study in Spanish or CSL. Instead, FLTE programs should be proud that the study of foreign languages make students interested in learning about other languages and cultures, not necessarily foreign, including their own. 


\section{- A CONSTANT OFFERING OF PROFESSIONAL DEVELOPMENT PROGRAMS (PDP)}

FLTE programs could benefit from inlcuding courses devoted to the history of languages, and to the sometimes bloody and violent historical background of the spread of languages and the "supremacy" of some languages and cultures over others. Likewise, it is paramount to offer subjects, very early in the program, that encourage critical thinking and positioning: the University must be the setting where students are offered the chance to wake up after twelve years of being mired in an oppressive system. Every course of the FLTE curriculum should be an opportunity to address "uncomfortable" topics such as migration, colonization and political refuge, just to name a few. All these "border conditions" (Bhabha, 1994, p. 29), sisters of war, exile and human displacement must move us if we are interested in the so-called intercultural communicative competences.

This preparation, however, should also be offered to in-service teachers who might not have had access to decolonial theories before. Usually there are salient gaps with in-service teachers because they not have an ample offering of venues to continue their preparation and reflections. A robust offering of PDP is needed around topics such as communitybased pedagogies, decolonial theories, social justice, and the place of languages in such fields. In-service teachers' participation in this constant discussion can be the foundation for an environment in which teachers' voices will be heard and taken into account as supplies bottom-up approaches to policy and national curriculum design, as recommended by different scholars (Cárdenas et al., 2015; Buendía \& Macías, 2019); and on the other hand, it would allow for reaching a consensus, negotiating the different perceptions, acknowledging differences and rebuking myths and misconceptions about decoloniality.

\section{BY WAY OF CONCLUSION}

All of these reflections are very far from constituting a thorough and comprehensive analysis of all the curricular aspects that can be improved in a FLTE program, but they might as well constitute a first step into the decolonizing path. The decolonization of the FLTE curriculum needs to establish mechanisms of constant reflection about our languages and the foreign ones, as well as the exploration of new pedagogical approaches that restore the balance of social justice; for instance, Community Based Pedagogies (Clavijo, 2015) and reflections around the concept of social justice are excellent tools to decolonize current visions of foreign language teaching and bilingualism as exclusive assets of elite education. Put in Hall's words (2016) "using English [or any other foreign language] in some manner is no longer a luxury; it must be part of that basic universal education we wish for all. Keeping English from anyone, whether actively or indirectly, must now be seen as a social injustice" (p. 3). In this sense, school curriculum has to strive for the development of agency in equity in its teacher and student bodies, so that a new kind of citizenship is formed: one that begets active decolonial participants of social change and social justice (Bassey, 2010).

\section{BIBLIOGRAPHIC REFERENCES}

Albornoz, F. (2012). ¿Educar para colonizar o descolonizar para educar? naturaleza y cultura en América Latina: Escenarios para un modelo de desarrollo no civilizatorio. Memorias del XVIII foro de estudiantes latinoamericanos de antropología y arqueología-FELAA. (pp. 329-340). Universidad Politécnica Salesiana, Quito, Ecuador. 
Altbach, P. (1971). Education and neocolonialism. Teachers College Record, 72 (4), 543558.

Bassey, M. O. (2010). Education for Civic Citizenship and Social Justice: A Critical Social Foundations Approach. Education as Change, 14 (2), 247-257

Bhabha, H. K. (1994). El lugar de la cultura. Manantial.

Castro-Gómez, S. \& Grosfoguel, R. (2007). El giro decolonial: Reflexiones para una diversidad epistémica más allá del capitalismo global. Editorial Siglo del Hombre.

Clavijo, A. (2015) Implementing Community Based Pedagogies with Teachers in Colombia to enhance the EFL curriculum. In Perales, M. y Méndez, M. (Eds.). Experiencias de docencia e investigación en lenguas extranjeras. pp. 31-43. Editorial Universidad Quintana Roo

Corbett, J. (2003) An Intercultural Approach to English Language Teaching. Multilingual Matters Ltd.

Foucoult, M. (1995). Discipline and Punish: The Birth of the Prison. (A. Sheridan, Tr.). Vintage

Freire, P. (1997). Pedagogía de la autonomía, saberes necesarios para la práctica educativa. Editorial Siglo XXI

García-González, V. (2020). Descolonización de los saberes del docente como base para la promoción e implementación de prácticas educativas significativas. CULTURA EDUCACIÓN Y SOCIEDAD, 12(1), 241-254. https://doi.org/10.17981/ cultedusoc.12.1.2021.16
Gómez, L. F. (2015). The cultural content in EFL textbooks and what teachers need to do about it. PROFILE Issues in Teachers' Professional Development, 17(2), 167187.

Griffith, R. L., Wolfeld, L., Armon, B. K., Rios, J., \& Liu, O. L. (2016). Assessing intercultural competence in higher education: Existing research and future directions (Research Report No. RR-1625). Educational Testing Service. http:// dx.doi.org/10.1002/ ets2.12112.

Hall, C. (2016). A short introduction to social justice and ELT. In C. Hastings \& L. Jacob (Eds.), Social Justice in English Language Teaching (pp. 3-10).: TESOL Press.

Jackson, J. (2014). Introducing Language and Intercultural Communication. Taylor and Francis.

Kontopoulos, Kyriakos. (1993). The Logics of Social Structures. Cambridge University Press.

Kramsch, C. (1993). Context and culture in language teaching. Oxford University Press

Kumaravadivelu, B. (2016) The Decolonial Option in English Teaching: Can the Subaltern Act? TESOL Quarterly, 50(1), 66-84.

Liddicoat, A. J., (2021) Foreword. In J.A., Álvarez Valencia, A. Ramírez, O. Vergara (Eds.) Interculturality in language teacher education: Theoretical and Practical Considerations (pp. 9-13). Programa Editorial Universidad del Valle.

Macedo, D. (2019). Decolonizing Foreign Language Education, The Misteaching of English and Other Colonial Languages. Routledge. 
McKay, S.L. (2021). The need for Diversity and Inclusion in ELT Texts (Conference). Anaheim University online Open TESOL Conference. August 28 ${ }^{\text {th }}, 2021$.

Mignolo, W. \& Tlostanova, M. (2009). Global Coloniality and the Decolonial Option. Kultur (Special Issue: Epistemologies of Transformation) 6, 130-147.

Mejía de, A. M. (2006). Bilingual Education in Colombia: Towards a Recognition of Languages, Cultures and Identities. Colombian Applied Linguistics Journal, (8), 152-168.

Miranda, N. (2016). Bilingual Colombia Program: Curriculum as Product, Only? Working Papers in Educational Linguistics (WPEL), 31(2), 2.

Monzó, L., \& McLaren, P. (2014) Critical Pedagogy and the Decolonial Option: Challenges to the Inevitability of Capitalism. Policy Futures in Education, 12(4), 513-224.

Núñez-Pardo, A. (2018), The English Textbook. Tensions from an Intercultural Perspective. GiST Education and Learning Research Journal, 17, 230259.

Núñez-Pardo, A. (2020). Inquiring into the Coloniality of Knowledge, Power, and Being in EFL Textbooks. HOW Journal, 27(2), 113-133

Palaiologou, N. \& Dietz, G. (2012). Multicultural and Intercultural Education Today: Finding a 'Common Topos' in the Discourse between Continents and Disciplines. In Palaiologou, N. \& Dietz, $\mathrm{G}$ (Eds.), Mapping the broad field of multicultural and intercultural education worldwide. (pp. 1-7), Cambridge Scholars Publishing
Popkewitz, T. (1999). Introduction. Critical Traditions, Modernisms, and the "Posts". In T. Popkewitz \& L. Fendler (eds)., Critical theories in education: Changing terrains of knowledge and politics. (pp. 1-13). Routledge.

Quijano, A. (1992). Colonialidad y Modernidad/ Racionalidad. Perú Indígena, 13(29), 11-20.

Ramírez, A., Colmenares, S., \& Castellanos, M. (2019). Desarrollo de la competencia comunicativa intercultural a través del trabajo con una obra literaria. Signo y Pensamiento, 38(74). https://doi. org/10.11144/Javeriana.syp38-74.dcci

Reagan, T., \& Osborn, T. (2019) Time for a Paradigm Shift in U.S. Foreign Language Education. In Donaldo $\mathrm{M}$. (ed) Decolonizing Foreign Language Education, The Misteaching of English and Other Colonial Languages. Routledge.

Shohamy, E. (2001). The power of tests: A critical perspective on the uses of language tests. Longman.

Solano-Alpízar, J. (2015). Decolonizing Education or Accepting the Challenge of Taking a Different Path. Revista Electrónica Educare, 19(1), 117-129. https://doi.org/10.15359/ree.19-1.7

Tomlinson, B. (2016). The Importance of Materials Development for Language Learning. En M. Azamoosh, M.m, Zeraatpishe, A., Faravani \& H. Reza (eds.), Issues in Materials Development (pp. 1 -9). Sense Publisher 
THE DECOLONIAL OPTION: IMPLICATIONS FOR THE CURRICULUM OF FOREIGN LANGUAGE TEACHER EDUCATION PROGRAMS

\section{Acknowledgements:}

All my gratitude to professor Jaime Usma, who conducted the seminar where this paper was gestated, and whose insightful comments, corrections and feedback made this paper possible. 